cus tuberculatus Beauv., hibernates as a larva and reaches maturity about May ist.

Dr. Cyrus H. Thomas in $187 \mathrm{r}$ described* a form of $S$. americana under the name of Acridium ambiguum and stated that in southern Illinois it always appears in small numbers in April or May while americana never appears earlier than the middle of July. In another place $\dagger$ he says of ambiguum: "It is this variety which appears occasionally to pass the winter in the perfect state." The specimens in my possession may be his var. ambiguum but as far as I can see they do not differ either in structure or color from specimens of the typical americana taken in this vicinity in October.

McNeill says of $S$. americana, that its earliest recorded appearance at Rock Island, Illinois, is Sept. 2oth $\ddagger$; while Scudder records its capture at Fort Reed and Jacksonville,Florida, on April roth.§ This comprises all the infor- mation at hand as to dates of appearance at other places.

That the species is, to a certain extent, migratory is well known, numerous instances of this habit having been recorded by Riley,* Thomas, and other writers; but these migrations all occurred in late summer or in autumn.

Its unexpected appearance here so early in the season gives rise in my mind to the following questions: Where, if at any place, in the United States does it hibernate as imago? Is it double or treble brooded in such a locality? At what point southwest of Terre Haute, Indiana, does it occur mature as early as April I 2th in sufficient abundance that it could be blown in numbers and scattered over the streets of this city? In this locality it is evidently double brooded, the first brood maturing in June or July from eggs hatched in spring, the other maturing in September or October.

\title{
HOSTS OF NORTH AMERICAN TACHINIDAE, ETC., I.
}

BY C. H. TYLER TOWNSEND, LAS CRUCES, N. MEX.

The following twenty-seven species of tachinids, sarcophagids, etc., were all bred by Prof. S. A. Forbes, in Illinois. They were included in a large collection of Muscidae sent to me for determination from the Illinois State

* U. S. geol. surv. of Montana, 1871, 447 .

† Psyche, VI, 73.

$\ddagger$ Ninth Rep. st. ent Ill., I880, 133 .

§ Proc. Bost. soc. nat. hist., XIX, 86.
Laboratory of Natural History at Champaign.

r. Cistogaster immaculata Mcq.One bred from Leucania unipuncta.

2. Ocyptera euchenor Wlk. - One bred from "Acrididae." Also one (smaller specimen) from Leucania unipuncta.

* First Rep. U. S. ent. comm., 449. 
3. Exorista phycitae Le Baron.Two specimens bred from Acrobasis indiginella.

4. Exorista hirsuta O. S. - One from Botis penitalis.

5. Exorista ciliata Twns. - Six from Hemaris diffinis. Two of the specimens have the red on sides of abdomen much like $E$. scudderi, but are apparently greased specimens of $E$. ciliata.

6. Exorista trivittata v. d. W.?One specimen, which may belong to this species, but is too broad-headed to be a typical Exorista, was bred from $A p a$ tela oblinita.

7. Masicera archippivora Riley.Eleven specimens bred from Danais archippus; and one from Clisiocampa sp.

8. Masicera schizurae Twns.-One bred "from pupae of Euchaetes egle. Breeding cage, May 4, I880"; and one "from larva."

9. Masicera nigrita Twns.?-Three specimens, which I doubtfully identify as this species, were bred from Gortyna nitela. Another specimen was bred from Gortyna sp. They all differ from the type in being less narrowed in form.

Io. Masicera eufitchiae Twns.Two specimens, a $\delta$ and a $\&$, which I can hardly separate from the type of this species from Colorado, were bred from Hyphantria textor. The $\delta$ issued July 30 , and the $q$ July 3 I. They seem to be hardly as robust as the type and not quite so bristly, but otherwise I cannot separate them. The $\delta$ has the sides of abdomen a little reddish, but the $q$ shows none of this color. The type specimen from Colo. is a $\delta^{\pi}$, and shows some reddish on sides of abdomen. Another difference to be noted is that the present bred pair shows the segments of the abdomen quite uniformly pollinose posteriorly as well as anteriorly, while the type shows the segments pollinose mainly at base, the rest being quite shining.

II. Nemoraea hyphantriae Twns. Mss.-Two bred from Hyphantria textor.

12. Nemoraea nigricornis Twns. mss.-Three bred from Hyphantria textor.

13. Miltogramma argentifrons Twns.-One bred from Leucania unipuncta.

14. Micropalpus fulgens Meig.Two specimens bred from "cutworm."

15. Phorocera edwardsii Will.One bred from "cutworms."

16. Phorocera comstocki Will.One from Botis penitalis; and one from Lophyrus sp.

17. Prospherysa promiscua Twns. -One bred "from pupae of Eucliaetes egle. Breeding cage, May 4, I88o."

18. Phasioclista metallica Twns.One specimen (apical cell closed) bred from Sphenophorus parvulus. Another specimen, which does not differ except that it has the apical cell open, was bred from Leucania unipuncta.

19. Macquartia sp?-One bred from "coleopterous larvae."

2o. Phrissopoda lamanensis R. D. Myod. 335. (Peckia)? - Desvoidy's description agrees quite well, both in size and color, with three $\delta$ specimens 
bred from Nephelodes minians. Two specimens show the whole face and front, even the frontal stripe in some lights, brassy golden; while the other one shows the facial depression and frontal stripe blackish. They might be identified with Sarc. sarraceniae Riley, but for the fact that the description and figure of the latter show no bushy hairs on posterior tibiae. This latter character indicates the species as belonging to the genus Phrissopoda. It is doubtful whether this is Desvoidy's species, however.

21. Sarcophaga helicis Twns.Nine specimens bred from "Lachnosterna"; nine from Pieris rapae; and two from Leucania unipuncta.

22. Sarcophaga oedipodinis Twns. Mss.-Thirteen specimens, bred from Heliophila unipuncta (?), I cannot actually separate from two specimens of above species sent me by Mr. Scudder, and bred from Dissosteira carolina captured at Niagara Falls.

23. Sarcophaga acrididarum Twns. Mss.-One bred from "Acrididae."

24. Sarcophaga sp. ठ.-Two from Leucania unipuncta. The species may be recognized by the following brief description :

Length, 9-1o mm. Face, sides of face, cheeks, and sides of front silvery whitish or cinereous; frontal stripe, antennae, palpi, and legs black; third antennal joint about twice as long as second. Thorax cinereous, with three black vittae, and a shorter one on each side; abdomen marmorate with silvery, cinereous, and black, three blackish vittae showing moderately distinct in an oblique light; anus fulvous. Marginal macrochaetae on third and fourth segments, less closely approximated on third segment. Femora ashy below. Venation typical of genus. One specimen, however, has the left apical cross vein bent in at an angle at base, and with a small stump projecting inward from the angle. Both are males, and the front is $\frac{1}{4}$ width of head. Row of small bristles on sides of face below near eye margins well pronounced.

A much smaller $\delta$ specimen ( $6 \mathrm{~mm}$.), also bred from L. unipuncta, has the anus more broadly fulvous, the face with more of a brassy tinge, the front hardly as wide proportionally. It is perhaps distinct.

25. Sarcophaga sp.-One from Leucania unipuncta. It may be described as follows :

Length, $5^{\frac{1}{3}} \mathrm{~mm}$. With much the facies of Miltogramma, but arista plumose on basal half. Wholly of a slightly brassy cinereous. Antennae rufous on second joint and base of third, palpi rufous Third antennal joint about $\mathrm{I}_{2} \frac{1}{2}$ times as long as second. Front $\frac{1}{3}$ width of head, frontal vitta $\frac{1}{3}$ width of front. Frontal bristles descending a little below base of antennae, 3 or 4 orbital bristles, a double row of minute bristles on sides of face extending upon sides of front. Vibrissae on oral margin. Thorax brassy cinereous, without distinct vittae. Scutellum with a long apical non-decussate pair of macrochaetae. Abdomen concolorous, only short bristly, anus tipped with fulvous. Venation typical of Miltogramma (and Sarcophaga). If this species is found to be undescribed, it may be known as $S$. leucaniae.

26. Ormia sp? - A $\delta$ bred from Crambus.

27. Lucilia caesar L. - Six bred from Leucania unipuncta.

Note.-I do not vouch for all of the above flies being true parasites. The hosts as given above are simply taken from the records of breeding sent me with the specimens by Professor Forbes. 

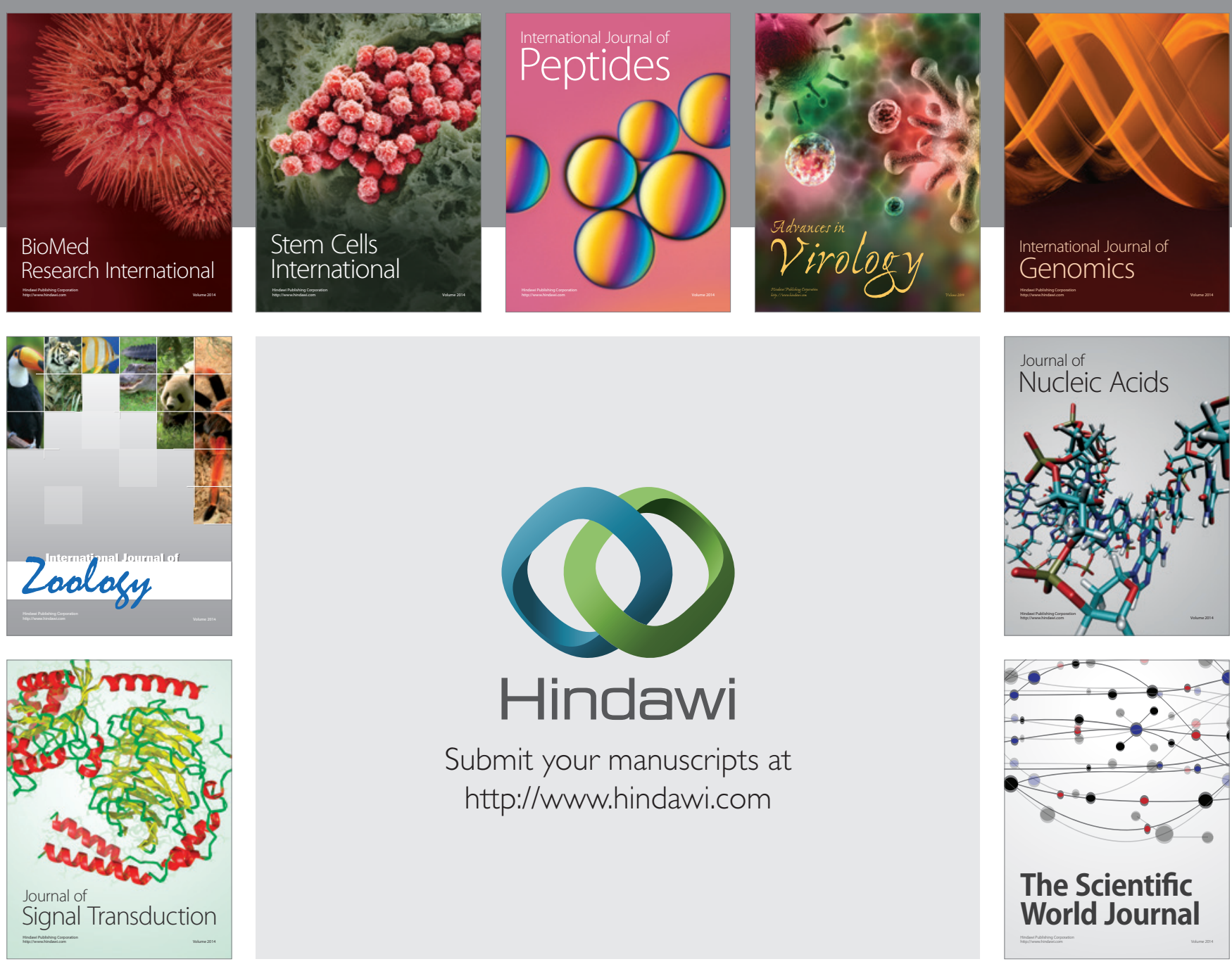

Submit your manuscripts at

http://www.hindawi.com
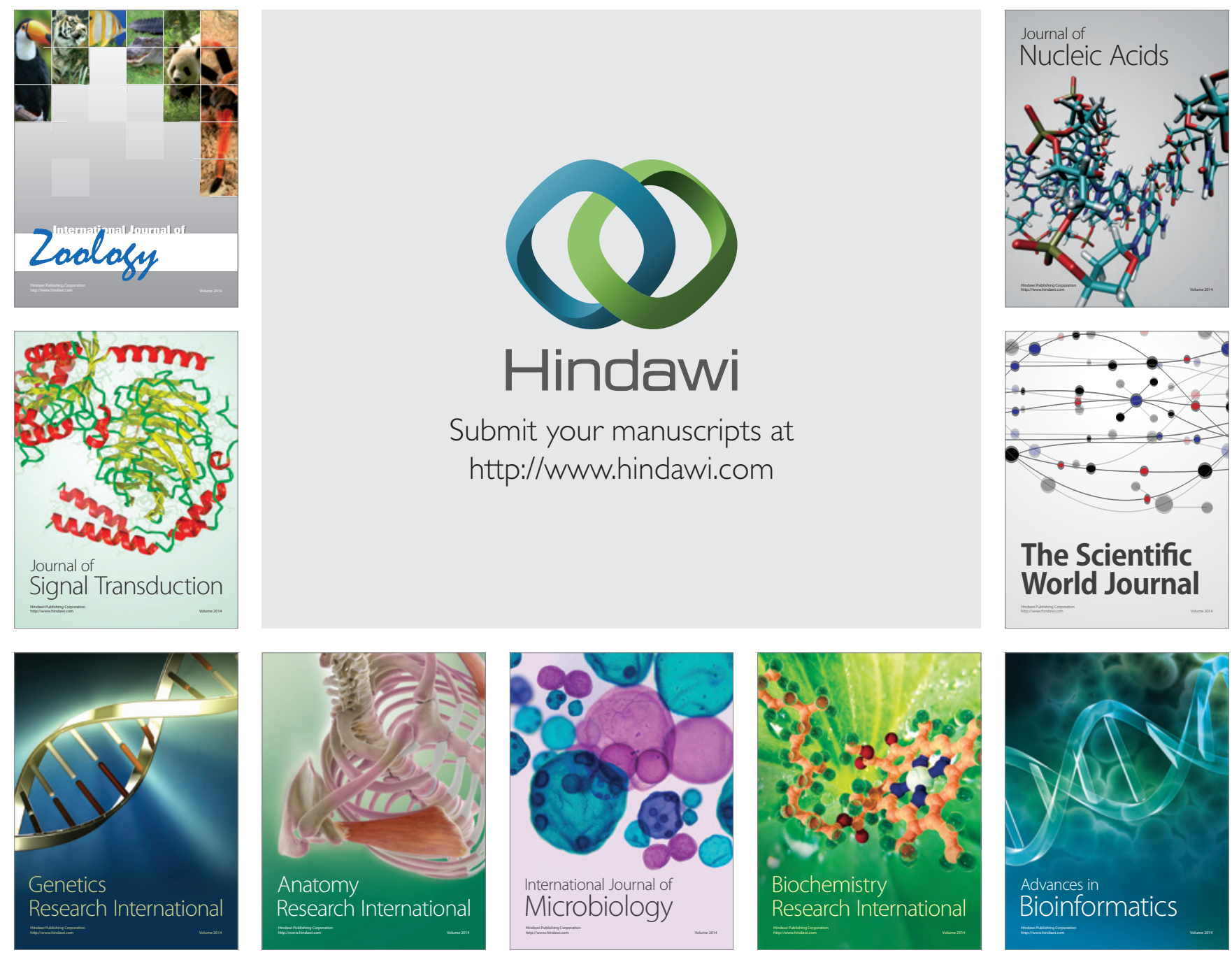

The Scientific World Journal
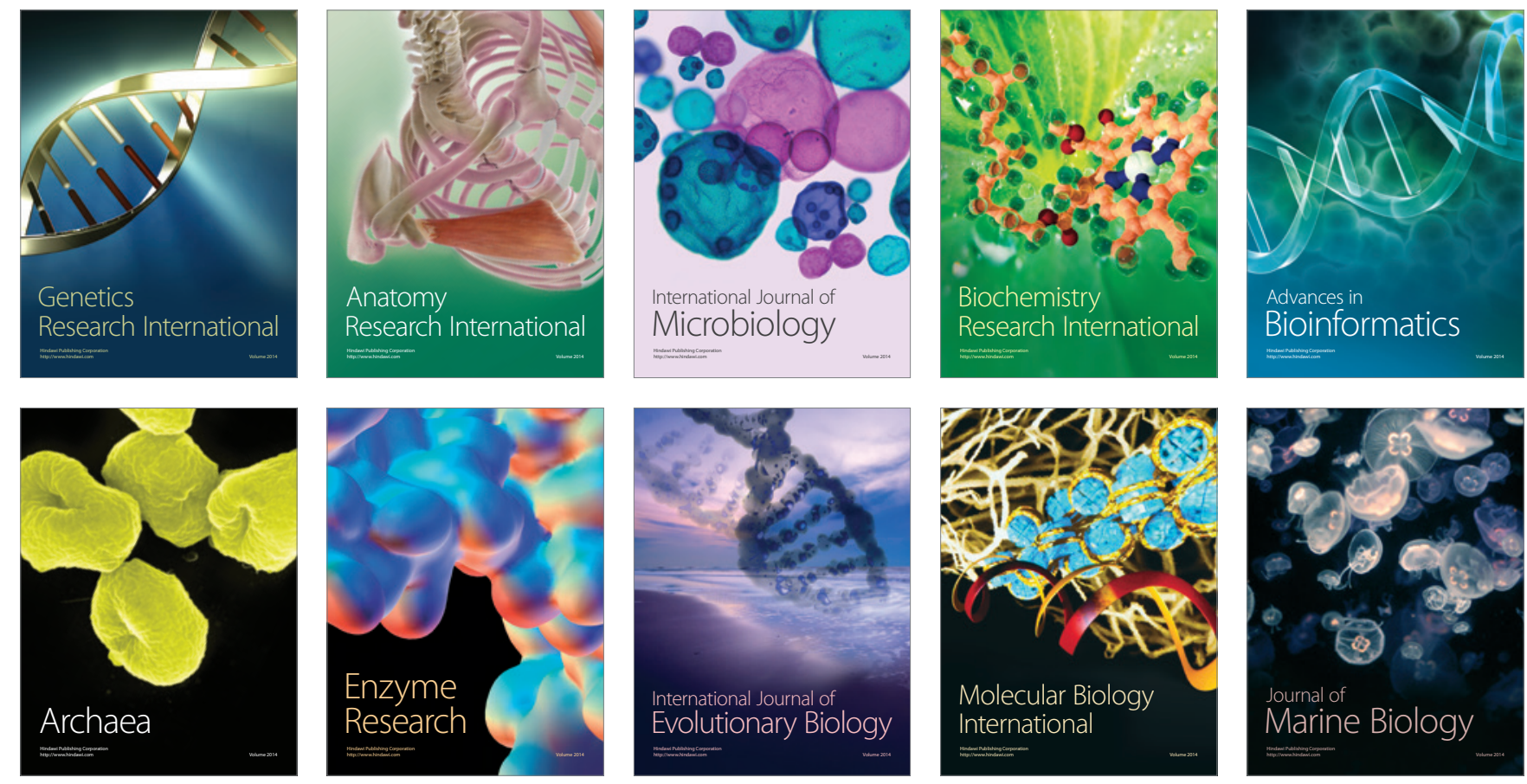